\title{
The establishment of ETOs in the context of externalised migration control
}

\author{
Kristof Gombeer and Stefaan Smis
}

\begin{abstract}
Affluent states increasingly seek to control migration beyond their borders. One means of doing this has been to relegate migration administration to third states. To illustrate, Australia places asylum seekers offshore, while the EU-Turkey agreement has served to limit the number of Syrian refugees able to access other parts of Europe. In addition, states have set up cooperative arrangements with transit states with problematic human rights records, such as Libya. These practices raise the question whether states remain responsible under human rights law for protecting migrants whose stakes are governed by the third countries with which they cooperate. The first part of this chapter describes the concepts of externalisation and outsourcing of migration control and provides illustrations from state practice. The second part analyses to which extent migration control beyond the border can trigger the applicability of human rights instruments. It is shown how the notion of 'human rights jurisdiction' may be further developed so as to accommodate for human rights checks on these emerging practices in the field of migration control.
\end{abstract}

\section{The transformation of migration control}

\section{Externalisation}

Today's prevailing view is that states have an 'undeniable sovereign right to control aliens' entry into and residence in their territory' (European Court of Human Rights (ECtHR) Amuur v. France, para. 41). Destination countries, however, do not wish to fully close off their borders as they rely on the movement of goods, services and labour to sustain their wealth (Jones 2016, pp. 165-166). Solutions to this dilemma have been sought within three different spaces: at the border, inside the border and before the border. More border checks impede the movement of goods and people, while fewer checks are said to diminish security. States have therefore tried to make administration and control at the border 'smarter' (Longo 2018, p. 141), or to manipulate the legal borders of parts of their territory to exclude migrants from judicial protection (see also Maillet in this volume). Techniques of control have also been pushed inward from the linear state border. Since administrations cannot fully filter unwanted movements at the border, they increasingly submit people under surveillance within their territory, ultimately resulting in 
detention and deportation. Affluent countries such as Australia, the USA and the member states of the EU increasingly attempt to control migratory movements before people reach their territories. The third space where today's migration control takes shape, is the one beyond the border: 'externalisation' seeks to prevent having to deal with control measures at and inside the border in the first place. The latest development, 'outsourcing', occurs when states rely heavily on third parties to realise such externalisation.

Externalisation rests on the belief that efficient control entails 'going beyond the place and time of the entry point' and 'locating where the migrant is in his or her process of moving towards an assumed destination point' to then stem that flow through the most effective method (Casas-Cortes and Cobarrubias 2019, p. 200). For example, the imposition of visa restrictions has proven an effective method to remotely control migrant mobility (Weber and Pickering 2011, p. 95). Since the second half of the twentieth century, visas have become a tool for targeting specific nationalities in general and refugee-producing countries in particular (FitzGerald 2019, pp. 59-60, 164-166 and 221-222; Moreno-Lax 2017, pp. 81-116). Absent legal pathways, migrants have been funnelled into using clandestine methods and routes towards the territories of destination states. Western states initially responded to this by pushing back migrants at or before they reach their territory. Yet, these methods of externalisation have been increasingly curtailed by ETOs (infra part 2). Outsourcing has therefore emerged as a 'hands-off' variant of externalisation based on the idea that affluent countries thereby might avoid legal responsibilities, including ETOs, towards migrants (Gammeltoft-Hansen and Hathaway 2015, p. 243; FitzGerald 2019). With outsourcing, destination countries have started to rely more and more on third states as the locus and executors of migration control measures.

\section{Outsourcing}

Outsourcing to third states can achieve migration control in three main ways. Firstly, outsourcing efforts may target (would-be) migrants directly by limiting their ability to enter or stay in transit countries. Third state entry control is usually employed to make the neighbours of affluent countries less attractive as a transit state. Third countries may be nudged to adopt legislation which enhances their control over inward movements of third country nationals, for instance, by emulating strict visa regimes. The outsourcing state may, for example, also finance deportations programmes of transit countries to dissuade the latter as transit options. Secondly, destination states may seek to outsource the provision of international protection such as asylum to third states. This is usually done by labelling the latter as 'safe countries' to which migrants can be returned. Third countries may be pushed to adopt legislation which enhances them as a 'safe' third country by reforming its asylum laws and refugee reception capacities and conditions. A variation of this outsourcing method consists of deviating migrants to the territory of third countries when migrants are en route to the destination state but are intercepted before they reach the latter's territory. Thirdly, outsourcing efforts may target the stakes of migrants by limiting their ability to exit third countries towards the ultimate destination countries. Third state exit control aims at containing migrants within the borders of the third state. To this end, the outsourcing state usually encourages the third state to adopt stricter anti-smuggling laws and to enhance its operational capacities to prevent migrants from leaving the latter's territory.

Outsourcing states themselves can be involved to varying degrees and use different means to galvanise cooperation. States may, for instance, use diplomatic sticks and carrots to incentivise states to take on migration control functions. They may provide direct financial incentives or directly provide equipment, assets and training. States may also deploy liaison officers, joint enforcement operations, the use of intergovernmental agencies and direct migration control in 
the territory of the cooperating state (Gammeltoft-Hansen and Hathaway 2015, pp. 250-256). In these instances, it is the state agents of the destination state itself that assert authority and/ or control over migrants, often - even though consent is needed from the cooperating third state - acting on a legal basis provided by the laws of the destination state. This can be thought of as externalisation but does not constitute outsourcing per se. Compare this, for instance, with the deployment of British immigration officers at the Eurostar terminal in Brussels. The authority and control over the stakes of the traveller here is not asserted by the cooperating third state (Belgium) but by the externalising state (United Kingdom). Techniques of outsourcing, however, attempt to shift the direct authority and control over the stakes of the migrant to the third state.

When destination states are themselves strongly operationally involved in control beyond their border, the fact that they exercise authority or control over the person of the migrant usually suffices to trigger the applicability of human rights law. However, it is when states seek $a$ deeper hands-off approach by relying heavily on the conduct of third states that establishing relations of duty for human rights purposes becomes more complicated. Before turning to the legal challenges for establishing ETOs in the context of externalisation and outsourcing of migration control, the next section provides examples of outsourcing in state practice. The section also points to human rights issues that may arise in the wake of such outsourcing efforts.

\section{State practice}

\section{Australia}

In a move to externalise and outsource responsibilities for migration control, Australia has initiated and funded both bilateral and regional initiatives with neighbouring countries. Central to its multilateral efforts is the Bali Process, established in 2002, whose role has mostly been limited to facilitating cooperation in addressing irregular migration (Kneebone 2014, pp. 599-606). Australia has also been able to rely on bilateral cooperation to outsource migration control areas far beyond its territory (Larking 2017). It has sought cooperation with countries of origin such as Sri Lanka and with countries of transit such as Malaysia. It has moreover concluded deals with countries such as Cambodia and the US with a view to resettle or exchange refugees, but these have been largely unsuccessful. Central to Australia's outsourcing efforts, however, has been its cooperation with Indonesia, Nauru and Papua New Guinea (PNG).

Efforts to outsource migration control to Indonesia have focused on legislative reform and on the prevention and disruption of unauthorised departures to Australia. This resulted first in the establishment of the Regional Cooperation Model in 2000 through which Australia encouraged and almost entirely financed the use of migrant detention. Australia has further provided financial and technical assistance, training of border and immigration officials, equipment, assets such as patrol vessels to enhance Indonesia's capacity to perform exit controls. Australia has moreover invested in Indonesia's entry control by influencing Indonesia to adopt stricter visa policies vis-à-vis refugee producing countries (Mussi and Feith Tan 2015, pp. 97-98).

Cooperation with PNG and Nauru has predominantly revolved around containment by outsourcing the status determination of migrants and their detention. In response to the $M / V$ Tampa incident, Australia supplemented its novel maritime interception programme ('Operation Relex') and excision of certain islands for migration purposes, with a mechanism to fully outsource status determination procedures to PNG and Nauru. Under what became known as the 'Pacific Solution', Australia concluded Memorandums of Understanding with both countries in 2001. It renewed them - after a brief interruption - again in 2012 and in 2013. The gist of this outsourcing mechanism is that Nauru and PNG host one or more so-called Regional 
Processing Centres, while Australia incurs their cost, including that of the additionally required infrastructure and services. Migrants eligible for international protection by PNG and Nauru are either 'settled' there or - with the assistance of Australia - in third countries. They are not resettled to Australia. This re-routing continued under subsequent administrations under 'Operation Sovereign Borders' (Phillips 2017).

\section{Europe}

European states have organised the outsourcing of migration control both as a matter of EU policy and at the level of the individual EU Member States engaging in bilateral relations with third states.

The EU has stressed the 'efficient management of migration flows at all their stages' in cooperation with countries of origin and transit since the 1999 summit in Tampere (European Council 1999). While in 2000 the Cotonou development agreement between the EU and the group of African, Caribbean and Pacific states made migration the subject of dialogue for both sides, the 2002 summit went a step further by conditioning closer relations between the Union and third countries on the latter's cooperation in 'combatting illegal immigration' (European Council 2002). In 2005, the European Council adopted the 'Global Approach to Migration' which prioritised cooperation with third countries in Africa and the Mediterranean, in particular Morocco, Algeria and Libya (European Council 2005). In 2011, this programme was renewed under the 'Global Approach to Migration and Mobility' (European Commission 2011). In 2015, the EU adopted a 'European Agenda on Migration' which continued on the path of stemming unauthorised migration via cooperation with third countries. Later that year, the Summit of Valletta reaffirmed the EU's focus on addressing the root causes of migration and stemming irregular migration through cooperation. An 'EU Emergency Trust Fund for Africa' was created to form the financial backbone of the scheme.

While some efforts at the level of the EU are genuinely directed at development, they are increasingly dominated by a logic of stemming onward movement of migrants. EU initiatives have tried to enhance the containment and buffer function of third countries through several techniques. Firstly, there is the export of EU modelled legislation, one of the EU's traditional modi operandi. New anti-smuggling laws temper the ability of clandestine movement (e.g. Niger's 2015 Law against Illicit Smuggling of Migrants), while improved laws on asylum, reception conditions and readmission attempt to enhance transit countries as bona fide safe countries for forcibly displaced migrants or as countries from which return can be organised (e.g. Morocco's revision of Immigration Law 02/03). The EU has also trained the local administrations (border guards, police, judges, asylum workers) to enhance the capacity to function as asylum states and to step-up the level of enforcement capacity. Europe moreover financially invested in third countries' buffer roles by providing surveillance and patrolling equipment, setting up information campaigns discouraging onward movement and funding information and reception centres (European Commission 2011, pp. 15-16). The EU's outsourcing targets have been situated increasingly further down the migration routes, to for instance the Sahel region (e.g. 'capacity-building mission' EUCAP Sahel Niger). For example, Niger on its own has received several hundred million euros to curb transit migration towards Libya and Algeria, in addition to the $€ 609$ million in earmarked development aid between 2016 and 2020 (Tubiana et al. 2018, p. 22). Combined, these strategies of outsourcing turn third countries in concentric buffer layers against onward movement towards Europe.

The second leg of European outsourcing efforts has rested on bilateral relations between individual European states on the one hand and third countries predominantly situated in the 
MENA and Sahel region on the other hand. Three examples are illustrative of the evolution of externalisation to outsourcing.

Spain has since the early 2000s developed cooperation with countries such as Morocco, Mauritania and Senegal to stem migration towards its land and sea borders. A central element to these exit control efforts has been the setting up of joint patrols to interrupt maritime departures within the territorial waters of third states. In 2004, for example, Spain launched a mission with the Moroccan Gendarmerie whereby Spanish Civil Guards joined on Moroccan patrol vessels. In 2006, Spain established a similar mechanism with Mauretania in which it moreover supplied Mauretania with patrol boats and trained its border control agents. In addition to operational involvement and support aimed at exit control, Spain has since the beginning invested heavily in linking development funding to migration control. For example, since 2006 Mauretania and Senegal have respectively received $€ 88.6$ and $€ 34.9$ million in aid destined for border control (Gonzalez Garcia 2020).

Italy has a long history of collaboration on migration control with Libya, the first formalised cooperation dating back to an agreement in 2000 addressing irregular migration among other things. Since then, Italian-Libyan cooperation has been governed by both formal and informal agreements. The agreements have come with large financial transfers, political support and the provision of equipment and patrol vessels in exchange for tighter Libyan exit control. These bilateral deals arranged for the joint patrolling of the waters off the Libyan coast with migrants intercepted being returned to Libya. With the removal of Gaddafi and the condemnation by the European Court of Human Rights of push-back operations by the Italian coast guard, cooperation was on a low but still alive: even amidst the civil war in 2011 did Italy seek cooperation with the National Transitional Council. Cooperation was fully revitalised through a 2012 Memorandum of Understanding, focussing on the exchange of liaison officers, readmission, training for the Libyan police, the recovery of detention centres, readmission from Libyan detention centres and the use of Italian drones to provide early detection of unauthorised maritime departures. This support was supplemented at the European level by an EU Border Assistance Mission to develop a Libyan border control strategy. In addition, EUNAVFOR MED Sophia (now operation IRINI) was transformed into a training and technical assistance mission in 2016. Italian outsourcing efforts - backed-up with EU support - have turned Libya in an effective actor preventing migrants from embarking upon journeys towards Europe (Spagnolo 2019; Campesi 2018; Mussi and Feith Tan 2015).

Given the strained relation between Greece and Turkey, cooperation with the latter has mainly come from the EU level. Given the increasing pressure on the EU's external border in Greece, a deal was struck in 2016 between the EU Member States on the one hand and Turkey on the other: visa liberalisation, the speeding up of the disbursement of 3 billion Euros under the 'Facility for Refugees in Turkey' and the re-energising of the process of accession of Turkey to the EU in return for Turkey's commitment to 'prevent new sea or land routes for illegal migration opening up from Turkey to the EU' and to take back 'all new irregular migrants crossing from Turkey into the Greek islands' (EU-Turkey Statement 2016).

\section{Externalisation, outsourcing and the establishment of ETOs}

By externalisating and outsourcing migration control, affluent states undeniably have an impact on the enjoyment of human rights by (would be) migrants. Australia's outsourcing efforts have shown to negatively impact the human rights of the migrants targeted through exit control, entry control and containment. In addition to issues of refoulement and the right to leave in light of Australian maritime pushbacks, the conditions of Australian-backed detention in 
countries such as Indonesia, PNG and Nauru have been denounced. This has not only been pointed out by NGOs, but by multiple states as well (Human Rights Council (hereafter 'HRC') 2015a, paras. 22-24; HRC 2015b, paras. 63 and 68; Human Rights Watch 2013; Papua New Guinea Supreme Court 2016); Achiume et al. 2017). Australia has, however, been dismissive of this critique, arguing that it has been respecting the human rights of those 'claiming protection within Australia's jurisdiction' and of the 'transferees' in its cooperation with third countries. What is more, Australia prides itself that through cooperation with third countries, it has been able to 'deter' people from undertaking 'dangerous sea journeys', thereby saving lives (Human Rights Council 2015, paras. 125-127). European cooperation with third countries has impacted the enjoyment of human rights of migrants in its wake as well. All along the south-north migration routes, migrants are increasingly prevented from exercising their right to leave, thereby exposing them to violence from law enforcement, militias and - as a result of tougher antismuggling laws - more ruthless methods employed by smugglers. Perhaps the most egregious case is that migrants re-displaced in places such as Libya are thereby becoming exposed to practices of torture, trafficking and enslavement (Moreno-Lax 2020a). Like Australia, Europe too has increasingly justified cooperation - despite the clear human rights impact - with third countries as contributing to the 'saving of lives' by for instance preventing them undertaking 'dangerous journeys' at sea (European Commission 2017).

A question that arises is to which extent the application of human rights norms and accompanying state obligations is triggered vis-à-vis these externalisation and outsourcing practices in the first place. For human rights purposes, the responsibility of states can arise in mainly two ways. Firstly, as a primary duty-bearer under the human rights instruments it is bound by (via the triggering of the so-called 'human rights jurisdiction' of the state), and secondly, as a dutybearer of a secondary order when another state is identified as the primary duty-bearer, but the outsourcing state can still be held responsible due to its relation to the violations committed by the former. This is, for instance, the case when a state aids and assists the primary duty-bearer in the commission of the human rights violation (see also Erdem Türkelli in this volume). While this section of the chapter as such does not look at the complementary role that the law on state responsibility may provide in this regard, certain features of ancillary responsibility are referred to when discussing the modalities of human rights jurisdiction. The primary goal of the remainder of this contribution is to identify the extent to which externalisation and outsourcing practices can be captured under notion of 'human rights jurisdiction'.

\section{The problem of 'jurisdiction' for human rights purposes}

Human rights treaties necessarily have to define whose rights the state has to protect. While some human rights instruments such as, for example, the ICCPR, CRC, ACHR and ECHR contain written provisions delineating their scope of application (referring either to 'territory', 'jurisdiction' or a combination thereof as the relevant benchmarks for their applicability) other human rights instruments, however, do not.

International and regional courts and human rights bodies have developed an extensive practice of interpreting the conditions for the extraterritorial application of these instruments (see also Pribytkova; Haeck, Burbano Herrera and Ghulam Farag in this volume). Meanwhile, scholars have attempted to find a coherent way to look at the rich material generated in practice. Some authors define 'jurisdiction', 'authority', 'public powers' or 'political power' over a person's stakes as the normative linchpin of primary duty (Besson 2012; Raible 2020). Others have emphasised the exercise of 'physical' or 'effective' control or 'actual power' over a person's situation (Milanovic 2011). Still others have argued that 'affecting' the enjoyment of rights or 
'the ability' to do so is what establishes relations of duty and thus the triggers applicability of human rights instruments (Shany 2013).

Turning to the issue of externalisation and outsourcing of migration control, justifications for establishing 'human rights jurisdiction' that rest on actual authority or control have only proven useful when state agents are themselves directly involved in the stakes of (would-be) migrants in a legislative, executive or judicial capacity. With regard to pushbacks by coast guard vessels at sea, for example, the European Court of Human Rights (hereafter 'ECtHR') deemed the European Convention applicable by virtue of both the de jure and de facto control over the migrants intercepted at sea. As a result, Italy was under the non-refoulement principle prohibited from returning the migrants concerned to Libya (ECtHR, Hirsi Jamaa v. Italy; see also Inter-American Court of Human Rights (hereafter 'IACtHR') 2018, para. 122).

Yet, even when state agents are directly involved, problems of attribution may undermine the establishment of jurisdiction for human rights purposes. Ship-rider techniques during patrolling, for example, or instances where civil servants of the outsourcing state not only train third country officials but also make decisions about applications by migrants, constitute more complicated cases: even though the agents of the outsourcing state exercise control and/or authority over migrants, this conduct may be considered as attributable to the neighbouring state.

Moreover, assertions of power over the migrant's situation abroad for the purposes of triggering human rights jurisdiction have not been recognised consistently: while in the past physically removing individuals from diplomatic premises (control) or the non-issuing of passports to nationals in embassies abroad (authority) were deemed sufficient to trigger 'jurisdiction' for human rights purposes (European Commission on Human Rights (hereafter 'ECmHR'), $M v$. Denmark and Human Rights Committee (hereafter 'HRCee'), Lichtensztejn v Uruguay respectively), the European Court of Human Rights recently ruled that the processing of a humanitarian visa request submitted by Syrians in Belgian consular premises in Beirut did not suffice to fall 'within the jurisdiction' of Belgium for the purposes of the Convention. As a result, the applicants concerned could not complain that the non-granting of a visa by Belgium would expose them to the risk of torture and ill-treatment in Syria (ECtHR M.N. and others v. Belgium; on ETOs arising in diplomatic premises; see also Wilde in this volume).

The classic models of authority and control over persons will especially be of no avail in the context of outsourcing, i.e. in situations no state agents of the outsourcing state are involved and where migration is not stemmed but for the conduct of the cooperating third state and the resulting power that they have over the stakes of migrants concerned. Two jurisprudential developments may nonetheless provide an avenue for establishing 'human rights jurisdiction' in those scenarios: when control over a situation can be established by virtue of a subordinate foreign administration (the proxy model) and when a state has the ability to affect the rights of the persons concerned (the effects model). The remainder of this section explores how these models could ensure that not only externalisation involving state agents of the destination state, but also involving projections of power over migrants' ability to move through third states (outsourcing) may end up within the scope of human rights instruments.

\section{Outsourcing and the proxy model}

When a state exercises power over an area abroad by using a subordinate local administration, this can serve as a basis for establishing human rights jurisdiction. Under the proxy model, a human rights treaty can apply when a state exercises overall control over an area by financing, equipping and politically and militarily supporting administrations or de facto regimes abroad. This doctrine has its roots in the Northern Cyprus and Transdniestria case law of the Strasbourg 
Court. In both contexts, the fact of control over the foreign area was enabled through the presence of troops on the ground (ECtHR Loizidou (preliminary objections), para. 63; ECtHR Ilascu, paras. 380 and 383). Financial and political support constitute further indicators to determine whether a foreign administration resorts 'under the effective authority, or at the very least under the decisive influence' of the state concerned (ECtHR Ilascu, para. 392). The sharing of military expertise and equipment can be of relevance too (ECtHR Chiragov, para. 180). The adoption of legislation by the proxy regime modelled on that of the influencing state is one of the other pieces to take into account when assessing the influence of one over the other (ECtHR Chiragov, para. 182). Importantly, it is not necessary for the state concerned to exercise detailed control over the policies and actions of the proxy administration (ECtHR Loizidou, para. 56). Interestingly, this distinguishes primary relations of duty under the proxy model from state responsibility arising from 'direction and control' pursuant to Article 17 ARSIWA. In sum, even though the individualised acts based on policies of the proxy administration are not as such imputable to the state concerned, the latter is nonetheless responsible for it by virtue of its overall control established by the presence of troops and influence gained through logistical, financial, economic and political means.

Under a strict reading of the law as it stands, it is not certain whether outsourcing efforts in a third state could trigger human rights jurisdiction under the proxy model, unless the outsourcing states become heavily involved on the ground. For instance, if the United States authorities would push for Mexican legislation emulating American immigration and border control standards, deploy US border guards for training and support at the border with Guatemala and pay for deportation flights for people detained at that border, this may still not meet the threshold of the proxy-model. Similarly, suppose the Libyan Coast Guard intercepts vessels or the Nigerien police confiscates vehicles used by smugglers, while Europe provided training, assets and model statutes to couch the whole enterprise in a legislative framework: this may still be not enough. After all, in all the judgments of the Strasbourg Court embracing the proxy model, the respondent states were always: 1) strongly military involved on the ground, 2) creating overall control over the foreign territory, while 3) the local administration - often a 'puppet regime' - survived by virtue of the support from the respondent state.

Nonetheless, an argument that can be developed and that lies within the reach of adjudicative bodies to embrace is that the proxy model does not necessarily have to aim at plain control over a foreign territory but may instead be applied to functionally limited areas of governmental activity. One such functional area of government activity could be migration control. Just as the exercise of authority (ECmHR $X$ and $Y v$ Switzerland; HRC Gueye) or control (HRC Saldias de Lopez) abroad can be functionally limited (whether exercised de jure or de facto), foreign subordinate administrations might be targeted as proxies for limited purposes.

A case in point would be the Libyan GNA after the removal of Gaddafi and the way it has been sustained not only to create stability in parts of Libya, but also to function as a tool for stemming migration towards the EU. As pointed out by inter alia Giuffré and Moreno-Lax (2019, pp. 105-106), Moreno-Lax (2020b) and Pijnenburg (2020, p. 326), both Italy and the EU have been heavily involved in Libyan exit control by the combined use of the Italian MRCC's coordination, intelligence sharing, the training of Libyan border guards, the provision of equipment and large assets such as patrol vessels and the deployment of an Italian vessel and staff in the port of Tripoli for technical support. If proxy control need neither cover an entire area nor a multiplicity of areas of governmental activity, Italy's efforts suffice to constitute functionally limited human rights jurisdiction by proxy. The same is true for Australia's outsourcing of processing to Nauru and PNG where asylum seekers their refugee status was to be determined by the local administration but with heavy financial, logistical and technical support from Australia. 
What these novel interpretations of the above-mentioned scholars do is increasingly isolate 'decisive influence' as a new autonomous basis for the triggering of primary duty, emancipating it from the context in which the proxy model came into existence: control over foreign territory through the use of puppet regimes. The challenge, then, lies in being able to establish decisive influence over a functionally limited area of governmental activity as a sufficient justification for the extraterritorial applicability of human rights law. It is a route taken by the Human Rights Committee in its observations with regard to Australian practices when it considered that 'significant levels of control and influence exercised by the state party over the operation of the offshore regional processing centres, including over their establishment, funding and service provided therein, amount to such effective control' (Human Rights Committee (hereafter 'HRCee') 2017, para. 35). It is to be seen whether human rights courts and other bodies will follow suit.

It should be noted that as the level of practical involvement on the ground of the outsourcing state becomes thus high, it can be qualified as an instance of externalisation through the use of state agents and resources, rather than an instance of outsourcing which is about leaving migration administration primarily up to the apparatus of foreign governments as is the case with for instance Turkey. Lower levels of involvement, on the other hand, may not suffice to trigger the outsourcing state to become an additional primary duty-bearer as the third state remains the one with actual political power over the stakes of the (would-be) migrants. This does not have to obstruct that the outsourcing state may incur legal responsibilities for human rights purposes of a secondary order, for instance, under the state responsibility rules on complicity. Contrary to the threshold of the proxy model which requires decisive influence, it suffices under Article 16 ARSIWA that a state's conduct merely contributed to the commission of human rights violations in order to entail the assisting state's responsibility for that aid. Different from responsibility as a result of human rights jurisdiction, however, aid and assistance would not entail the responsibility of the outsourcing state for the human rights violations themselves, but only for act of giving aid and assistance to the cooperating third state.

\section{Outsourcing and the effects model}

According to the effects model, the applicability of a human rights instrument can be triggered when state conduct has an effect on the enjoyment of rights even when the person whose rights are affected is situated abroad and the state lacks authority or control over the stakes of the person concerned. Purely causal models for establishing human rights jurisdiction are in an early stage of development in legal practice. Drozd and Janousek (ECtHR 1992, para. 91) and Munaf (HRCee 2009, paras. 7.5 and 14) are often cited as precedents recognising the effects model. While they did indeed employ the language of 'effects', they in fact did not established anything along the lines of cause-and-effect doctrine for establishing human rights jurisdiction. Strasbourg cases which could potentially be conceived of as instantiations of the effects model, such as Pad (ECtHR 2007, paras. 6 and 54) and Kovačić (ECtHR 2004, p. 52(c)) can also rather be categorised under the control model (physical control over persons established through the firing from a helicopter) and authority model (legislative authority over banking services of banks operational abroad), respectively. An affirmative judicial opinion has, however, come from the Inter-American Court of Human Rights, opining that effective control over a domestic source causing extraterritorial harm impacting the human rights of persons abroad suffices to trigger human rights jurisdiction (IACtHR 2017, paras. 101-102 and 104).

The state of the art of the case law aside, theoretically the effects model differs from models emphasising authority or control in that the latter are supposed to involve effecting the stakes of a person (in casu the power to determine the status or control the movement of (would-be) 
migrants), while the former only involves the affecting or the ability to affect the stakes of a person (cf. Raible 2020, pp. 106-113). Practically, a continuum may exist between effecting and affecting the stakes of individuals. Both Lawson and Shany, for instance, require state conduct as a cause to be sufficiently close and tangible to its effects in order to bring about the primary duty of states (Lawson 2004, p. 104 ('direct and immediate link'); Shany 2013, p. 69 ('direct, significant, and foreseeable')). Per these views, relations of duty should evaporate as causal chains stretch out too far. Other commentators, however, have argued to follow through further along the causal chain (Salomon 2013, pp. 280-282; Vandenhole 2007, pp. 87-88). Principle 9 of the Maastricht Principles, for instance, suggests that a state incurs obligations in situations over which state acts or omissions bring about foreseeable effects on the enjoyment of economic, social and cultural rights, whether within or outside its territory. It requires these effects neither to be direct (or 'immediate') nor to be significant (cf. Lawson and Shany). As models for triggering human rights obligations seek to explain their relation to notions of justice, they may not only climb down the causal chain but also introduce temporal aspects of causation as relevant to the establishment of duty; for instance, by introducing past wrongs and their continuing effects (Achiume 2019; Miller 2007, Chapter 6).

The implications for bringing the outsourcing of migration control within the ambit of the human rights instruments are complicated along these lines. When techniques of migration control end up in direct and reasonably foreseeable human rights abuses, this may entail the 'human rights jurisdiction' of the outsourcing state and thus trigger the applicability of the human rights instrument at hand. The direct affecting of the EU-Turkey deal of exit options of vulnerable migrants at variance with the right to leave may be a case in point. Incentivising transit states to enhance their state apparatus and legislation, as we saw with, for instance, Niger and Morocco, and the human rights abuses that might arise as a result, may however be too remote. Much will depend on how far judicial and monitoring bodies are willing to go down the causal chain for establishing human rights jurisdiction. This would indeed require relaxing the combined qualifying criteria of directness, significance and foreseeability of the connection between the power projected by the outsourcing state and the actual power exercised by the third state over the migrant.

\section{Conclusion}

Territorial migration control ordinarily does not pose any problems in terms of the applicability of human rights law: being subjected to the authority and control of state officials in airports, harbours or land crossing points suffices to engage the state not to return persons away where this would prejudice their human rights. The link between the efforts of affluent states to control migration outside their borders and the negative impact this has on the rights of (wouldbe) migrants is less straightforward but undeniable nonetheless. However, while human rights courts and bodies have been able to call out states on the human rights implications of a first wave of externalisation methods, a second generation of such externalisation efforts has arisen in response to this judicial oversight: western destination states more frequently and intensely rely on the involvement of third states to stem migratory movements towards their territories. The first generation of externalisation was relatively easy to accommodate under the concept of human rights jurisdiction by virtue of the externalising states' use of state agents to assert authority and/or control over the stakes of migrants. The second generation of outsourcing, however, precisely seeks to avoid these assertions of authority and control over the person of the migrant to function as a catalyst for relations of duty to arise. 
More than the first generation of externalisation of migration control, outsourcing challenges the classic vocabulary available to human rights lawyers. It should encourage them to explore and develop understandings of 'human rights jurisdiction' or other concepts for that matter which are able to capture the actual relations of power which continue to inform (enhance even) the control of affluent states over the mobility of people. This contribution depicted two promising avenues in this regard: the proxy model and the effects model. It is in the zones between effecting and affecting, between control and influence, between direct and indirect, between present and past assertions of power that concepts await further research. Through carefully crafting piecemeal changes in these models' margins, lawyers may convince adjudicators to take these models beyond the contexts in which they were conceived and to adapt them to projections of state power in the context of migration control. Absent progressive developments in legal practice, advocates may still seek to rely on ancillary forms of state responsibility for outsourcing practices of states. The challenge there lies not so much with meeting the conditions for establishing complicity under the rules on state responsibility but in finding out to which extent affected migrants may seek standing before the relevant courts and bodies absent finding themselves 'within the human rights jurisdiction' of the potential respondent states.

\section{References}

Achiume, E.T. (2019) 'Migration as Decolonization', Stanford Law Review 71(6), 1509-1574.

Achiume, E.T. et al. (2017) 'The Situation in Nauru and Manus Island: Liability for Crimes Against Humanity in the Detention of Refugees and Asylum Seekers', Communiqué to the Office of the Prosecutor of the ICC.

Besson, S. (2012) 'The Extraterritoriality of the European Convention on Human Rights: Why Human Rights Depend on Jurisdiction and What Jurisdiction Amounts to', Leiden Journal of International Law 25(4), 857-884.

Campesi, G. (2018) 'Italy and the Militarisation of Euro-Mediterranean Border Control Policies' in Burroughs, E. and Williams, K. (eds.). Contemporary Boat Migration: Data, Geopolitics, and Discourses, Rowman \& Littlefield.

Casas-Cortes, M. and Cobarrubias, S. (2019) 'Genealogies of Contention in Concentric Circles: Remote Migration Control and its Eurocentric Geographical Imaginaries' in Mitchell, K. et al. (eds.). Handbook on Critical Geographies on Migration, Elgar.

European Commission (EC) (2011) Communication from the Commission to the European Parliament, the Council, the European Economic and Social Committee and the Committee of the Regions - The Global Approach to Migration and Mobility, 18 November 2011, COM(2011) 743 final.

(2015) Communication from the Commission to the European Parliament, the Council, the European Economic and Social Committee and the Committee of the Regions: A European Agenda on Migration, 13 May 2015, COM(2015) 240 final 8-9.

(2017) 'Migration on the Central Mediterranean route: Managing flows, saving lives', Joint Communication to the European Parliament, the European Council and the Council, 25 January 2017.

European Commission of Human Rights (ECmHR) (1977), X and Yv Switzerland (App. No. 7289/75). (1992), M.v Denmark (App. No. 17392/90).

European Council (2016), EU-Turkey statement, 18 March 2016, press release. (2002), Presidency Conclusions of the Seville European Council of 21-22 June 2002. (1999), Presidency Conclusions of the Tampere European Council of 15-16 October 1999.

European Court of Human Rights (ECtHR) (1992), Drozd and Janousek v France and Spain (App. No. 1274/87). (1995), Loizidou v. Turkey (preliminary objections) (App. No. 15318/89). (1996), Loizidou v. Turkey (App. No. 15318/89). (2004), Ilaşcu and Others v. Moldova and Russia (App. No. 48787/99). 
(2004), Kovačić and Others v. Slovenia (App. Nos. 44574/98 and others).

(2007), Pad and Others v. Turkey (App. No. 60167/00).

(2012), Hirsi Jamaa and Others v. Italy (App. No. 27765/09).

(2015), Chiragov and Others v. Armenia (App. No. 13216/05).

(2020), M.N. and Others v. Belgium (App. No. 3599/18).

FitzGerald, D.S. (2019) Refuge Beyond Reach: How Rich Democracies Repel Asylum Seekers, Oxford University Press.

Gammeltoft-Hansen, T. and Hathaway, J. (2015) 'Non-Refoulement in a World of Cooperative Deterrence', Columbia Journal of Transnational Law 53(2), 235-284.

Giuffré, M. and Moreno-Lax,V. (2019) 'The Rise of Consensual Containment: From Contactless Control to Contactless Responsibility for Migratory Flows' in Juss, S.S. (ed.). Research Handbook on International Refugee Law, Elgar.

Gonzalez Garcia, I. (2020) 'Immigration in Spain: Migratory Routes, Cooperation with Third Countries and Human Rights in Return Procedures' in Ippolito, F. et al. (eds.). Bilateral Relations in the Mediterranean. Prospects for Migration Issues, Elgar.

Human Rights Committee (HR Cee) (1983), Lichtensztejn v Uruguay (Comm. No. 77/1980).

(1984), Saldias de Lopez v. Uruguay (Comm. No. 52/1979).

(1989), Gueye and Others v. France (Comm. No. 196/1985).

(2009), Munaf v. Romania (Comm. No. 1539/2006).

(2017) Concluding observations on the sixth periodic report of Australia, CCPR/C/AUS/ CO/6, 1 December 2017.

Human Rights Council (HRC) (2015a) UPR Summary prepared by the OHCHR - Australia A/HRC/ WG.6/23/AUS/3.

(2015b), UPR Compilation prepared by the OHCHR - Australia A/HRC/WG.6/23/AUS/2.

(2015c), National report of Australia submitted in the context of the Universal Periodic Review, A/HRC/WG.6/23/AUS/1.

Human Rights Watch (2013) Barely surviving. Detention, Abuse, and Neglect of Migrant Children in Indonesia.

Inter-American Court of Human Rights (IACtHR) (2017), Advisory Opinion 23/17.

IACtHR (2018), Advisory Opinion 25/18.

Jones, R. (2016) Violent borders. Refugees and the right to move, Verso.

Kneebone, S. (2014) 'The Bali Process and Global Refugee Policy in the Asia-Pacific Region', Journal of Refugee Studies 27(4), 596-618.

Larking, E. (2017) 'Controlling Irregular Migration in the Asia-Pacific: Is Australia Acting against its Own Interests?', Asia \& Pacific Policy Studies 4(1), 85-103.

Lawson, R. (2004) 'Life after Banković: On the Extraterritorial Application of the European Convention on Human Rights' in Coomans, F. and Kamminga, M.T. (eds.). Extraterritorial Application of Human Rights Treaties, Intersentia.

Longo, M. (2018) The Politics of Borders. Sovereignty, Security, and the Citizen after 9/11, Cambridge University Press.

Milanovic, M. (2011) Extraterritorial Application of Human Rights Treaties: Law, Principles, and Policy, Oxford University Press.

Miller, D. (2007) National Responsibility and Global Justice, Oxford University Press.

Moreno-Lax,V. (2017) Accessing Asylum in Europe. Extraterritorial Border Controls and Refugee Rights under EU Law, Oxford University Press.

Moreno-Lax,V. (2020a) EU External Migration Policy and the Protection of Human Rights, European Parliament's subcommittee on Human Right.

(2020b) 'The Architecture of Functional Jurisdiction: Unpacking Contactless Control', German Law Review 21(3), 385-416.

Mussi, F. and Tan, N.F. (2015) 'Comparing Cooperation on Migration Control: Italy-Libya and AustraliaIndonesia', Irish Yearbook of International Law 10, 87-108.

Papua New Guinea Supreme Court (2016), Belden Norman Namah and Others v PNG (SC1497). 
Phillips, J. (2017) 'A Comparison of Coalition and Labor Government Asylum Policies in Australia since 2001', Research Paper Series, Parliament of Australia, February 2017.

Pijnenburg, A. (2020) 'Containment Instead of Refoulement: Shifting State Responsibility in the Age of Cooperative Migration Control?', Human Rights Law Review 20(2), 306-332.

Raible, L. (2020) Human Rights Unbound:A Theory of Extraterritoriality, Oxford University Press.

Salomon, M.E. (2013) 'Deprivation, Causation and the Law of International Cooperation' in Langford, M. et al. (eds.). Global Justice, State Duties, Cambridge University Press.

Shany,Y. (2013) 'Taking Universality Seriously: Functional Approach to Extraterritoriality in International Human Rights Law', Law \& Ethics of Human Rights 7(1), 47-71.

Spagnolo, A. (2019) 'The Conclusion of Bilateral Agreements and Technical Arrangements for the Management of Migration Flows: An Overview of Italian Practice', Italian Yearbook of International Law 28(1), 209-230.

Tubiana, S. et al. (2018) Multilateral Damage: The Impact of EU Migration Policies on Central Saharan Routes, Clingendael.

Vandenhole, W. (2007) 'Third State Obligations under the ICESCR: A Case Study of EU Sugar Policy', Nordic Journal of International Law 76, 73-100.

Weber, L. and Pickering, S. (2011) Globalization and Borders. Death at the Global Frontier, Palgrave MacMillan. 